\title{
Distribution of ampullary pores on three catshark species (Apristurus spp.) suggest a vertical-ambush predatory behaviour
}

\author{
D. M. Moore* , I. D. McCarthy \\ School of Ocean Sciences, College of Natural Sciences, Bangor University, Menai Bridge, Anglesey LL59 5AB, UK
}

\begin{abstract}
Apristurus is a genus of typically small sharks that inhabit deep waters around the globe. Relatively little is known about the feeding behaviour of these species. Here, the electrosensory biology of 3 species, A. aphyodes, A. melanoasper and A. microps, was investigated. Intra-specific variation in ampullary pore abundance was high in all species, highlighting the need for studies to examine multiple individuals. Abundance and distribution of ampullary pores on the head indicate that all 3 species are vertical ambush predators.
\end{abstract}

KEY WORDS: Apristurus aphyodes $\cdot$ A. melanoasper $\cdot$ A. microps $\cdot$ Rockall Trough $\cdot$ Ampullae of Lorenzini

\section{INTRODUCTION}

Electroreception in elasmobranchs is thought to facilitate various types of behaviour, including social interaction (Sisneros et al. 1998) and navigation (Paulin 1995, Montgomery \& Walker 2001). However, by far the most important use of electroreception in elasmobranchs is believed to be predator/prey detection (Kalmijn 1971, Raschi et al. 2001). The distribution of ampullary pores in elasmobranchs has been studied in numerous species (Fishelson \& Baranes 1998, Kajiura 2001, Atkinson \& Battaro 2006), and there is an increasing interest in mapping ampullary pore distribution as a tool to infer behaviour and ecology (Fishelson \& Baranes 1998, Kajiura 2001, Atkinson \& Bottaro 2006, Kempster \& Collin 2011a,b). Some published works of this field adopt a traditional meristical approach, whereby ampullary pores are counted and mapped from a single individual and taken as typical for the species (Kempster \& Collin 2011a,b), particularly in large or rarely sighted shark species. As most studies take data from multiple individuals, this study

\footnotetext{
*Corresponding author: dm_moore@hotmail.co.uk
}

will attempt to examine intra-specific variation in ampullary pore counts and furthermore elucidate the reliability of single individual representations.

The majority of studies on elasmobranch electroreception to date have focussed on coastal or upper pelagic species, and few on species from deep water environments, owing to limited accessibility. However, there is a growing need to better understand the ecology of deeper-dwelling species such as Apristurus spp., which are under increasing pressure from both targeted and non-targeted fishing. The genus Apristurus Garman, 1913 comprises 36 recognised species, which are poorly understood. We suggest that the ecology of Apristurus spp. may be inferred from ampullary pore distribution, by comparison with species in which their ecology is better studied.

At least 5 species of Apristurus are found in the Rockall Trough, Northeast Atlantic, an area under intense fishing pressure from Europe (Neat et al. 2008): A. aphyodes Nakaya \& Stehmann, 1998; A. laurussonii (Synonym A. maderensis) Saemundsson, 1922; A. manis Springer, 1979; A. melanoasper Iglésias,

๑ T The authors 2014. Open Access under Creative Commons by Attribution Licence. Use, distribution and reproduction are unrestricted. Authors and original publication must be credited. 
Nakaya \& Stehmann, 2004, and A. microps Gilchrist, 1922. Three of these species (selected due to availability of useable sample numbers) shall be the focus herein.

A. aphyodes lives in depths of 1014 to $1800 \mathrm{~m}$, from $49^{\circ} 1.9^{\prime} \mathrm{N}$ to $60^{\circ} 49.7^{\prime} \mathrm{N}$ (Nakaya \& Stehmann 1998). It preys upon crustaceans, cephalopods and small teleost fishes (Duffy \& Huveneers 2004). It is classed as Data Deficient on the IUCN Red List of Threatened Species.

A. melanoasper inhabits waters from 512 to at least $1520 \mathrm{~m}$ depth and is distributed across the North Atlantic between $39^{\circ} 17^{\prime} \mathrm{N}$ and $61^{\circ} 06^{\prime} \mathrm{N}$ (Iglésias et al. 2002). It is classed as Data Deficient on the IUCN Red List and there are currently no studies on its diet.

A. microps inhabits waters between 700 and $1200 \mathrm{~m}$ depth in both the North and South Atlantic Ocean. It feeds on small teleost fishes, crustaceas and cephalopods (Compagno et al. 1989) and is classed as Least Concern on the IUCN Red List.

All 3 species are regularly caught as by-catch in the deep-water fisheries of the Rockall Trough region (F. C. Neat, pers. comm.), but there are no detailed assessments.

\section{MATERIALS AND METHODS}

Specimens of Apristurus spp. were collected during a Marine Scotland Science deep-water trawl survey of the Rockall Trough area during September 2009 (see Moore et al. 2013). A maximum equal-sex and -length stratified subsample was taken, consisting of $20 \mathrm{~A}$. aphyodes $\left(100^{\top}\right.$ and 10o), $10 \mathrm{~A}$. melanoasper (50 and 5o) and 18 A. microps (90 and 9 o). Heads of specimens were removed by a single dorsoventral cut just posterior of the 5th gill slit, as all ampullary pores were found anterior of this point upon visual inspection. Heads were frozen for transportation.

After defrosting in a warm water bath, heads were examined using a Schott KL 1500 fibre optic cold light source (Fig. 1). Digital images were taken using a Ricoh Caplio R6 7.2 megapixel camera and then subsequently used for drawing of pore maps using Paint v6.1. Pores were counted in situ by direct visual inspection with counted pores marked in ink to limit observer error. Pore density estimations were established following Raschi (1986), utilising ImageJ picture analysis software.

Data were tested for normality (Anderson-Darling) and homoscedasticity (Hartlets) to ensure that assumptions made by statistical tests were met.

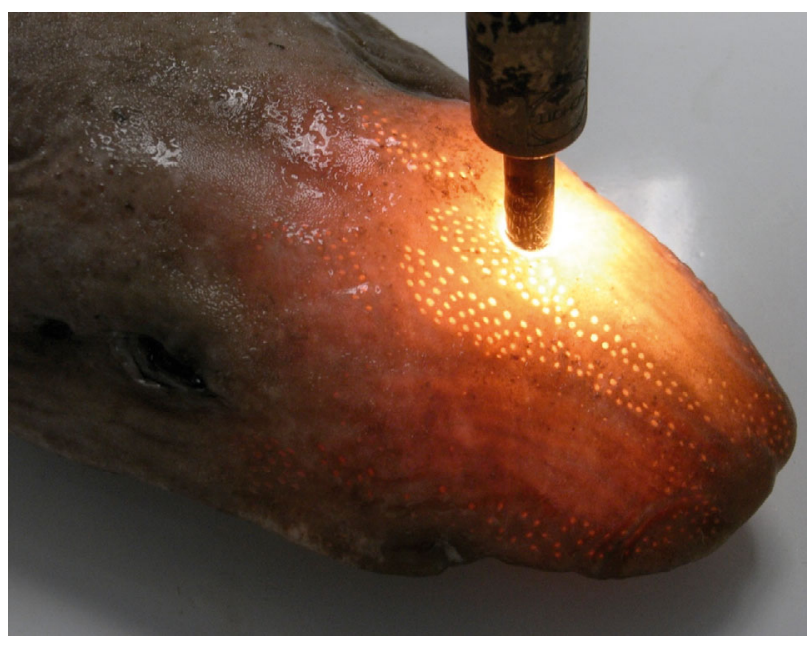

Fig. 1. Use of a fibre optic cold light source to highlight electrosensory pores in Apristurus microps

\section{RESULTS}

All 3 Apristurus species showed similarity in their pore grouping distribution pattern (Fig. 2). Most pores were grouped around the anterior snout region of the head, with only $12.1 \pm 1.4 \%$, $9.0 \pm 0.7 \%$ and $11.3 \pm 1.5 \%$ (mean $\pm \mathrm{SD}$ ) of pores being positioned posterior to the eye in $A$. aphyodes, A. melanoasper and A. microps, respectively. There was large intra-specific variation from the mean total pore count for all species. Variation from the mean was found to be highest in A. aphyodes at up to $20.6 \%$ (177 pores). Intra-specific variation in mean total pore count was $18.5 \%$ and $13.0 \%$ for $A$. melanoasper and A. microps respectively. All 3 species displayed variation in pore aperture diameter.

Total pore counts in $A$. aphyodes ranged from 761 to 1037 . Female $A$. aphyodes had significantly more pores than males with a mean $( \pm \mathrm{SD})$ pore count of 898 and 822 , respectively (Table 1 ; Kruskal-Wallis test, $H_{20}=7.41, \mathrm{p}=0.007$ ). There was no significant difference in total length (TL) between the sexes $\left(\right.$ ANOVA, $\left.F_{(1,18)}=0.60, p=0.448\right)$. Both males and females displayed significantly higher pore counts and pore density on the dorsal surface than on the ventral surface (Table 1; ANOVA, $\sigma^{7} F_{(1,19)}=91.97$, $\mathrm{p}<0.001$, o $\left.F_{(1,19)}=108.19, \mathrm{p}<0.001\right)$. There was no significant relationship between pore count and TL $\left(\mathrm{GLM}, \mathrm{r}^{2}=0.91, F_{(1,15)}=1.75, \mathrm{p}=0.357\right)$.

Total pore counts in $A$. melanoasper ranged from 1355 to 1781 . There was no significant difference between males and females (ANOVA, $F_{(1,9)}=0.03$, 

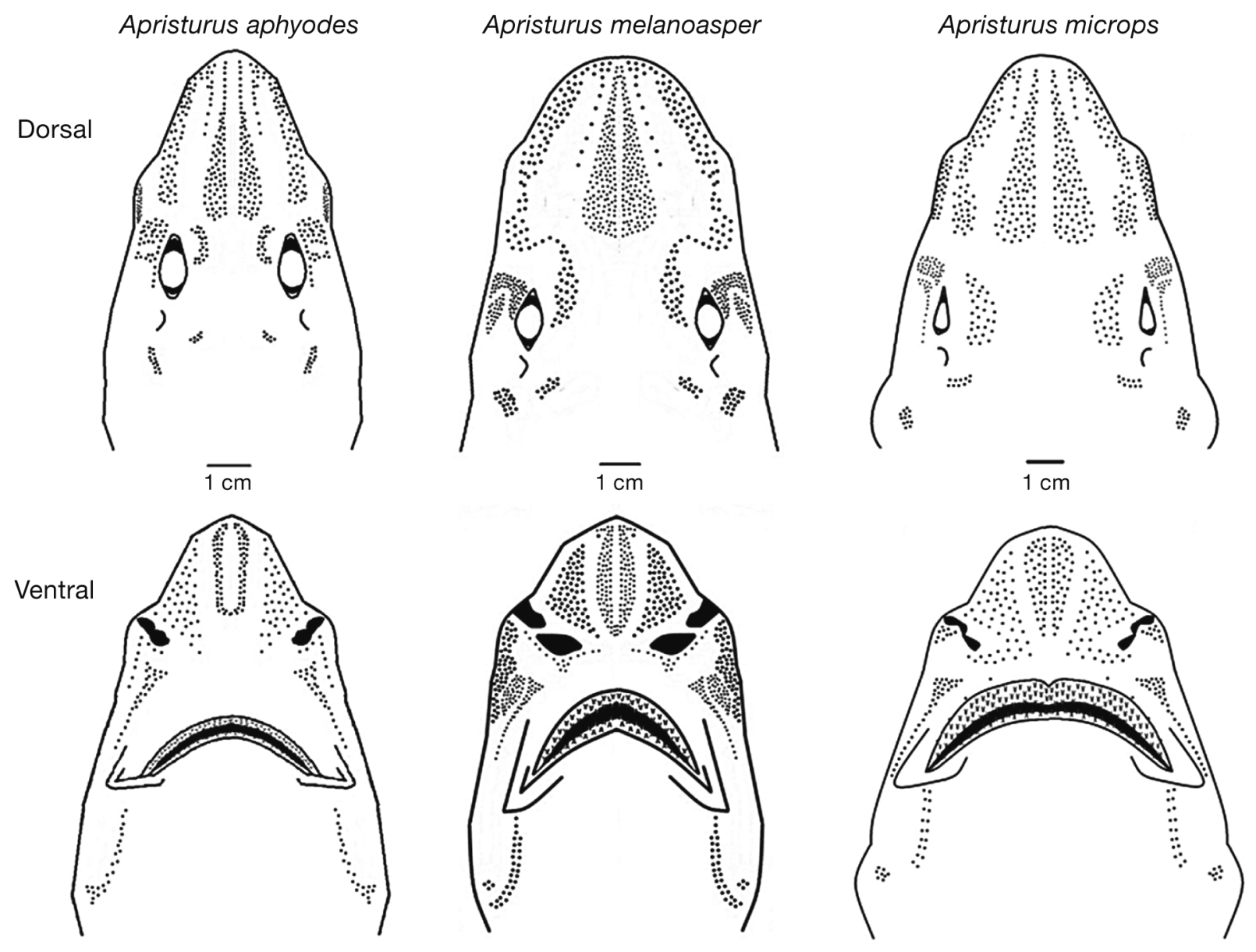

Fig. 2. Comparison of ampullary pore regions between Apristurus aphyodes, A. melanoasper and A. microps showing dorsal and ventral perspectives. Representations are not to scale

$\mathrm{p}=0.869)$. The difference in TL between sexes was significant (Kruskal-Wallis test, $H_{10}=5.77, \mathrm{p}=0.016$ ). There were no significant differences between dorsal and ventral pore counts (ANOVA, of $F_{(1,9)}=1.41, \mathrm{p}=$ 0.269 , o $\left.F_{(1,9)}=1.34, \mathrm{p}=0.281\right)$, nor between pore count and TL (GLM, $\left.\mathrm{r}^{2}=0.07, F_{(1,9)}=0.52, \mathrm{p}=0.496\right)$. A. melanoasper displayed a higher mean pore den-

Table 1. Total pore count (mean $\pm \mathrm{SD}$ ) and mean total length (TL) for Apristurus aphyodes, A. melanoasper and A. microps by sex

\begin{tabular}{|c|c|c|c|c|c|c|c|c|c|c|}
\hline \multirow[t]{2}{*}{ Species } & \multirow[t]{2}{*}{ Sex } & \multirow{2}{*}{$\begin{array}{l}\mathrm{TL} \\
(\mathrm{cm})\end{array}$} & \multicolumn{4}{|c|}{ - Pore number } & \multirow[b]{2}{*}{ Ventral } & \multirow[b]{2}{*}{$\pm \mathrm{SD}$} & \multicolumn{2}{|c|}{ Pore density } \\
\hline & & & Mean & $\pm \mathrm{SD}$ & Dorsal & $\pm \mathrm{SD}$ & & & $\begin{array}{r}\text { Dorsal } \\
\text { (por }\end{array}$ & $\begin{array}{l}\text { Ventral } \\
\text { es/cm²) }\end{array}$ \\
\hline Apristurus & M & 44.8 & 822 & 70 & 495 & 49 & 326 & 25 & 10.35 & 6.65 \\
\hline aphyodes & $\mathrm{F}$ & 46.9 & 898 & 81 & 559 & 62 & 339 & 26 & 11.69 & 6.91 \\
\hline Apristurus & $\mathrm{M}$ & 60.2 & 1496 & 165 & 716 & 83 & 780 & 86 & 13.90 & 14.58 \\
\hline melanoasper & $\mathrm{F}$ & 45.2 & 1511 & 121 & 732 & 44 & 779 & 80 & 14.21 & 14.56 \\
\hline Apristurus & $\mathrm{M}$ & 56.0 & 910 & 69 & 585 & 54 & 325 & 21 & 10.91 & 5.66 \\
\hline microps & $\mathrm{F}$ & 52.1 & 923 & 56 & 596 & 41 & 327 & 22 & 11.12 & 5.69 \\
\hline
\end{tabular}

sity (Table 1) on the ventral surface than on the dorsal surface, and the highest pore densities of the 3 species.

Total pore counts in A. microps ranged from 820 to 1035, with no significant difference between males and females (ANOVA, $F_{(1,18)}=0.21, \mathrm{p}=0.653$ ). There was no significant difference in TL between the sexes $\left(\right.$ ANOVA, $F_{(1,18)}=0.70$, $\mathrm{p}=0.415)$. Both males and females displayed significantly higher pore counts and pore density on the dorsal surface than on the ventral surface (ANOVA, $\sigma^{1} \quad F_{(1,19)}=$ $204.99, \mathrm{p}<0.001$, o $F_{(1,17)}=$ 302.08, p < 0.001). There was no significant relationship between pore count and TL $\left(\mathrm{GLM}, \mathrm{r}^{2}=0.01, F_{(1,18)}=0.01\right.$ ， $\mathrm{p}=0.914)$. 


\section{DISCUSSION}

All species of Apristurus displayed similar characteristics in their ampullary pore distribution pattern, including bi-lateral symmetry and concurrency with previously generated pore maps for other species within this genus (Cornett 2006). The dorsal surface displayed distinct longitudinally arranged central and peripheral pore regions to the anterior of the eye, a crescent region above the eye and two smaller regions posterior to the eye. Similarities in ventral surface distribution included a double line of pores running longitudinally posterior of the mouth, a roughly triangular pore assemblage anterior of the nares and a longitudinal region in the mesial zone of the snout. This distribution pattern was also found in A. brunneus (Cornett 2006) and is likely common to the whole genus. Only A. microps had pores in the labial area. Total pore counts for Apristurus spp. were high, compared to other scyliorhinids (Kajiura 2010). Maximum pore density was typically in the pore assemblages below the eyes, although in A. melanoasper pore density in this region was also equalled by that of the mesial snout assemblages.

Only $A$. aphyodes showed sexual dimorphism in total pore count, females having significantly higher numbers of ampullary pores. However, Fishelson \& Baranes (1998) also found the highest number of pores on female individuals of another carcharhiniform, the Oman shark Iago omanensis, which suggests sexual dimorphism in total pore counts could be interesting area of future research. Neither A. aphyodes nor A. microps showed significant differences in TL between sexes and it is likely the positive result for A. melanoasper is due to low sample size. With this in mind it is likely that intra-specific variation in total pore number is not linked to sexual dimorphism and is more likely of genetic origin.

The higher pore counts on dorsal surfaces than ventral surfaces in A. aphyodes and A. microps are not concurrent with findings for other deep water habitat species such as Galeus melastomus or Etmopterus spinax where ventral pores were more numerous (Atkinson \& Bottaro 2006). Both G. melastomus and E. spinax hunt fast-moving pelagic prey (Wurtz \& Vacchi 1981) and a higher ventral pore number may suggest that these species hunt by ambushing prey found below them in the water column. The higher dorsal pore number in A. aphyodes and A. microps suggests a more benthic existence; this higher dorsal pore number may facilitate detection of passing prey or predators above. This suggestion of vertical ambush is further reinforced by the depressed morphology of the snout and head within all study species. However this can be countered by the sub-terminal position of the mouth in all 3 target species which would only be concurrent with targeting prey from above; a strategy made more likely in $A$. melanoasper by its higher pore count being on the ventral surface. The labial pores in A. microps may suggest some in-sediment feeding and would therefore suggest that the increased mean pore number on the dorsal surface is more for detection of predators than prey. The mean pore densities in all 3 target species (Table 1) match the relationship displayed by the mean pore number; density however provides a much better indication of electroreception resolution (Raschi 1986). Following this, both $A$. aphyodes and $A$. microps have greater electroreception resolution on the dorsal surface, whereas it is on the ventral surface that $A$. melanoasper exhibits the greater electroreception resolution.

Mauchline \& Gordon (1983) outline stomach contents for unidentified Apristurus spp. as being mainly composed of decapod crustaceans with an ontogenetic shift in diet to include more cephalopods and crustaceans with increasing total length. In addition, Ebert et al. (1996) also showed a mixed diet of teleosts and crustaceans for Apristurus spp., but in the South Atlantic. Such a varied diet over the sharks' lifetimes is likely to suggest that Apristurus spp. are opportunistic generalist feeders and the conflicting sensory/morphological evidence supports this. Such a feeding strategy is also very agreeable in a deepwater environment where feeding opportunities are likely intermittent.

There was no significant relationship between total length and pore count in any species, suggesting Apristurus spp. individuals are born with a set number of electrosensory pores which remain active throughout their lives, as found in other shark species (Kajiura 2001, Raschi \& Gerry 2003, Cornett 2006, Mello 2009). However, the increase in TL with age necessarily results in a decrease in pore density as pore number remains constant. High pore densities are correlated with less mobile prey (like epifaunal and infaunal crustaceans) whereas lower pore densities are correlated with more mobile prey (like cephalopods and teleosts), due to a reduction in resolution as pore density decreases (with age-related growth), leaving the animal less able to detect immobile prey items (Jordan 2008, Bedore et al. 2014). It is therefore likely that the ontogenetic diet shift as described by Mauchline \& Gordon (1983) is driven by both a reduced ability to detect more immobile prey and an increase in mouth gape size that allows it to target larger prey items. 
Intra-specific variation in total pore count was high $(>10 \%)$ for all target species, as found in other studies (Jordan 2008, Bedore et al. 2014), but is unlikely due to observer error owing to the marking methodology employed. Future research should aim to understand to what extent, if any, such variation has on electrosensory capability. In addition, identifying the species' prey would assist in understanding the significance of pore distribution patterns in these deep-water elasmobranch species.

Acknowledgements. The Marine Scotland Science deepwater trawl survey (Cruise 1209S) was funded by the Scottish Government (Grant MF0763). Thanks go to Francis Neat (Marine Scotland) and the skipper and crew of the FRV 'Scotia' for assistance in obtaining samples. Additional thanks go to E. G. Cunningham and M. Kurr as well as 3 anonymous referees for constructive comments that have improved this manuscript.

\section{LITERATURE CITED}

Atkinson CJL, Bottaro W (2006) Ampullary pore distribution of Galeus melastomus and Etmopterus spinax: possible relations with predatory lifestyle and habitat. J Mar Biol Assoc UK 86:447-448

Bedore CN, Harris LL, Kajiura SM (2014) Behavioral responses of batoid elasmobranchs to prey-simulating electric fields are correlated to peripheral sensory morphology and ecology. Zoology 117:95-103

Compagno LJV, Ebert DA, Smale MJ (1989) Guide to the sharks and rays of southern Africa. New Holland, London

Cornett AD (2006) Ecomorphology of shark electroreceptors. MS thesis, Florida Atlantic University, Boca Raton, FL

Duffy C, Huveneers C (2004) Apristurus aphyodes. IUCN Red List of Threatened Species.Version 2010.4. www. iucnredlist.org (accessed 26 January 2013)

Ebert DA, Cowley PD, Compagno LJV (1996) A preliminary investigation of the feeding ecology of catsharks (Scyliorhinidae) off the west coast of southern Africa. S Afr J Mar Sci 17:233-240

> Fishelson L, Baranes A (1998) Distribution, morphology, and cytology of ampullae of Lorenzini in the Oman shark, Iago omanensis (Triakidae), from the Gulf of Aqaba, Red Sea. Anat Rec 251:417-430

Iglésias SP, Du Buit MH, Nakaya K (2002) Egg capsules of deep-sea catsharks from eastern North Atlantic, with first description of the capsule of Galeus murinus and Apristurus aphyodes. Cybium 26:59-63

Jordan LK (2008) Comparative morphology of stingray lateral line canal and electrosensory systems. J Morphol 269:1325-1339

Kajiura SM (2001) Head morphology and electrosensory pore distribution of carcharhinid and sphyrnid sharks. Environ Biol Fishes 61:125-133

Editorial responsibility: Christine Paetzold, Oldendorf/Luhe, Germany
Kajiura SM (2010) Sensory adaptations to the environment: electroreceptors as a case study. In: Carrier JC, Musick JA, Heithaus MR (eds) Sharks and their relatives. II. Biodiversity, adaptive physiology and conservation. CRC Press, Boca Raton, p 393-433

Kalmijn AJ (1971) The electric sense of sharks and rays. J Exp Biol 55:371-383

Kempster RM, Collin SP (2011a) Electrosensory pore distribution and feeding in the megamouth shark Megachasma pelagios (Lamniformes: Megachasmidae). Aquat Biol 11:225-228, doi:10.3354/ab00311

> Kempster RM, Collin SP (2011b) Electrosensory pore distribution and feeding in the basking shark Cetorhinus maximus (Lamniformes: Cetorhinidae). Aquat Biol 12: 33-36, doi:10.3354/ab00328

Mauchline J, Gordon JDM (1983) Diets of the sharks and chimaeroids of the Rockall Trough, North Eastern Atlantic Ocean. Mar Biol 75:269-278

> Mello W (2009) The electrosensorial pore system of the cephalofoil in the four most common species of hammerhead shark from the southwestern Atlantic. C R Biol 332: 404-412

> Montgomery J, Walker M (2001) Orientation and navigation in elasmobranchs: which way forward? Environ Biol Fishes 60:109-116

Moore DM, Neat FC, McCarthy ID (2013) Population biology and ageing of the deep water sharks Galeus melastomus, Centroselachus crepidater and Apristurus aphyodes from the Rockall Trough, north-east Atlantic. J Mar Biol Assoc UK 93:1941-1950

Nakaya K, Stehmann M (1998) A new species of deep-water catshark, Apristurus aphyodes n. sp., from the eastern North Atlantic (Chondrichthyes: Carchariniformes: Scyliorhinidae). Arch Fish Mar Res 46:77-90

Neat F, Burns F, Drewery J (2008) The deepwater ecosystem of the continental shelf slope and seamounts of the Rockall Trough: a report on the ecology and biodiversity based on FRS scientific surveys. Fish Res Serv Int Rep 02/08

Paulin MG (1995) Electroreception and the compass sense of sharks. J Theor Biol 174:325-339

Raschi W (1986) A morphological analysis of the Ampullae of Lorenzini in selected skates (Pisces, Rajoidei). J Morphol 189:225-247

Raschi WG, Gerry S (2003) Adaptations in the elasmobranch electroreceptive system. In: Val AL, Kapoor BG (eds) Fish adaptations. Science Publishers, Plymouth, p 233-258

Raschi W, Aadlond C, Keithar ED (2001) A morphological and functional analysis of the ampullae of Lorenzini in selected galeoid sharks. In: Kapoor BG, Hara TJ (eds) Sensory biology of jawed fishes. Science Publishers, Plymouth, p 297-316

Sisneros JA, Tricas TC, Luer CA (1998) Response properties and biological function of the skate electrosensory system during ontogeny. J Comp Physiol A 183:87-99

Wurtz M, Vacchi M (1981) Ricerca di cicli nittemerali nell'alimentazione di selaci batiali. Quad Lab Tecnol Pesca 3(Suppl 1):155-164

Submitted: November 25, 2013; Accepted: August 29, 2014 Proofs received from author(s): October 9, 2014 